\title{
Reshaping regional institutions: APEC and the IMF in East Asia.
}

\section{Mark Beeson}

The economic and latterly political crises that continue to grip East Asia raise important questions about both the way such events are best managed and about the way they should be understood. Although attention has thus far understandably focused primarily on the possible causes of the crisis or the sorts of policies that might alleviate its most immediate effects, it is also forcing a re-evaluation of a number of key theoretical issues which are central to conceptions of the region and its future evolution. Given that one of the key determinants of any possible future regional developmental trajectory will be the institutional infrastructure that emerges in the wake of the crisis, it is timely to consider the theory of institutions as well as their possible construction in the wake of the crisis.

The shaping of the region's institutional architecture has, in fact, become a major issue and object of political contestation in attempts to resolve the crisis. Consequently, the crisis has had the effect of sharply revealing differences in approach between two key inter-governmental agencies - the Asia Pacific Economic Cooperation (APEC) forum and the International Monetary Fund (IMF) - in their respective approaches to crisis management in particular and institutional development more generally. Before the crisis struck it might reasonably have been expected that APEC, rather than the IMF, would have played the most prominent role in trying to manage the crisis. After all, APEC is the only organisation that includes all the key players involved in the unfolding crisis, and is concerned principally with issues of economic management. And yet APEC has been conspicuous by its absence, the IMF having assumed the dominant role in both the attempted management of the crisis and - more importantly in the longerterm - in fundamentally re-shaping the region's economic and political institutions.

The very distinctive roles played by APEC and the IMF reveal much about both the different logics, assumptions and expectations that inform these organisations and their 
approach to institutional reform. A consideration of the different approaches taken by APEC and the IMF to the crisis also casts a revealing light on different theoretical understandings of institutions and their evolution. Although it is not being suggested here that there is a direct causal relationship between a particular theoretical position and subsequent policy, a reconsideration of institutional theory in light of the crisis can tell us much about the usefulness of particular theories in themselves, and help us to understand both the course of the current crisis and its possible future evolution. In what follows, therefore, I initially undertake a survey of the more useful and/or influential variants of institutional theory, before considering the role of APEC and the IMF, and their attempts to shape regional institutions.

\section{Institutional theory}

For all their prominence in theoretical debates and everyday life, there are remarkably varied views about what institutions actually are. Depending on the definition, phenomena as varied as marriage, the monarchy or Manchester United can be considered as such. Plainly, this is a signifier of some flexibility. Indeed, so elastic a notion may be considered too imprecise to aid our understanding of complex patterns of social activity. Yet it is possible to gain a more precise idea of what institutions may be by considering the notion's utilisation within discrete disciplines. This is not only a revealing exercise in itself, but it also illuminates the way in which specific conceptions of institutions have come to influence patterns of economic and social organisation. While there may be no simple correlation between the theoretical models that dominate academic discourse and the sorts of policies implemented by national political elites, neither are they unrelated: clearly they reflect and help construct the ontological reality policy-makers inhabit.

One of the more influential theorists of institutions, Robert Keohane, has suggested that particular conceptions of, or ideas about, social or political orders act as 'road maps', influencing the construction of policy and ultimately becoming embedded in political institutions (Goldstein and Keohane 1993: 3). This is a persuasive notion: clearly, policy makers develop policy based on a particular, socially constructed understanding of the 
'reality' they inhabit (Berger and Luckmann 1971). I shall consider Keohane's position more fully below, but there is an important implication to be drawn from his contention about the importance of ideas that is of particular relevance here. If our understanding of political and economic 'reality' is essentially ideational, this means that, as Wendt (1992: 399) points out, institutions themselves are 'fundamentally cognitive entities that do not exist apart from actors' ideas about how the world works'. In other words, the form institutions ultimately take is not determined exogenously, but bound up with the beliefs, values and intellectual traditions of the participants.

This has been an especially important consideration in APEC's case. The way institutions are conceived amongst APEC's non-Asian members in particular reflects the ideational dominance of a distinctively Anglo-American intellectual tradition that makes important ontological assumptions, not the least of which being about the potential for 'rational' goal-oriented action and the benefits of cooperation. Although the IMF shares many of the goals that are central to APEC's reform agenda, in contrast to APEC it has displayed a willingness to use direct political and economic leverage to achieve its aims, of which re-shaping a number of national institutions throughout the region is amongst the most central. At the very least, this reveals interesting differences in thinking within these organisations about the most efficacious ways of achieving institutional change. In order to draw out these differences and the assumptions that inform them, I shall review the some of the more important contributions to institutional theory. Such an analysis is timely, both as a test of the continuing utility of various theoretical positions in light of the crisis, and because they may have much to tell us about future institutional development in the region. To facilitate this discussion and explicate the manner in which institutions have been theorised, it is helpful to discriminate between disciplinary traditions in economics and political science, however arbitrary and limiting this distinction may be in practice. 
It needs to be acknowledged at the outset that attempting to demarcate between economics and politics at the level of theory, let alone in brute material reality, is an inherently artificial exercise. Nevertheless, it is possible to distinguish distinctive schools of thought in which institutions loom large. Even within those strands of institutional theorisation that are most closely identified with economics, however, it is possible to distinguish sub-groups and chronological ruptures. The 'old' and 'new' forms of institutional economics are characterised by very different methodologies and foci. The old institutional theory, of which Thorstein Veblen and John Commons are, perhaps, the most celebrated proponents, was descriptive, holistic, collectivist by orientation and against formalism. The new economic institutionalism, on the other hand, is invariably formalist, individualist, reductionist, 'orientated toward rational choice and economising models, and generally anti-interventionist' (Rutherford 1994: 4).

There is an important methodological shift between the old and new institutionalisms, which has had a significant influence on both theory and practice. At a theoretical level, Cammack (1992: 403) suggests that it is possible to identify a strand of institutionalist thought predicated upon methodological individualism, an orientation that reflects an inherent functionalism and which finds expression in rational choice theory. In this formulation, in other words, institutions are considered to move toward greater degrees of 'efficiency' in response to the rationally expressed 'needs' of utility maximising and calculating individuals. The second discrete perspective Cammack identifies - a sociological or historical-structural version of institutionalism - has generally been more closely associated with political science. What is important to note here, however, is that the individualistic, rational choice variety of institutionalist thought, which draws much of its theoretical inspiration from neoclassical economics, has exerted a profound influence on the political science discipline itself and ultimately, as we shall see, on political practice (Leys 1996: 38).

In some variants of the new institutionalism, economic practices are isolated from politics, and attention is focused on specific institutional forms like firms or markets. For theorists like Oliver Williamson (1985: 17), for example, institutional development is to be understood as a function of the desire to reduce 'transaction costs'. In other 
words, institutions' principal rationale is economic, and they will inevitably evolve toward increasingly 'efficient' and complex forms of organisation if they are allowed to do so. Moreover, Williamson (1993: 121) contends that transaction cost economics is an approach that is universally valid, and can explain the developmental trajectories of the Anglo-Americans economies and those of East Asia. However, the concept of 'path dependency' - one of institutional economics' most useful contributions - suggests that this universality may be more apparent than actual. The idea of path dependency emphasises that new institutions emerge from, or changes occur to existent institutions, within established patterns of institutional organisation.

Douglass North has been one of the most important and interesting of the new institutionalists. North has provided something of a bridge between an institutionalism based on rational choice theory, like Williamson's (and, as we shall see, Keohane's), and an historical institutionalism that takes contingent historical circumstance seriously. ${ }^{1}$ For North (1994: 359), institutions 'form from the incentive structure of a society, and the political and economic institutions, in consequence, are the underlying determinants of economic performance'. Although North (1990a: 5) stresses that institutions vary across time and space and influence subsequent patterns of development, his analysis seeks to build upon, rather than replace, the 'choice theoretic approach of neoclassical economic theory'. Institutions, then, are the 'rules of the game', or 'the humanly devised constraints that structure human interaction' (North 1995: 23). Despite North's determination to continue working within the neoclassical paradigm, his work represents an important and influential recognition of the influence of historical contingency, and the possibility that institutional development will not necessarily reflect narrowly conceived (Anglo-American) definitions of economic efficiency on the one hand, nor inevitably converge on functionally optimal end-points on the other.

Several points emerge from this discussion of North's work and are worth emphasising. First, in North's formulation institutional (and national) development is path dependent. Depending how such institutions are defined, this may include not simply economic organisations, but political and even cultural constellations. ${ }^{2}$ Second, the quest for increasing economic efficiency may not be the principal, or even a significant 
determinant of institutional form or development. ${ }^{3}$ Such considerations introduce an altogether more complex conception of institutions and their potential impact on the course of economic and political development. Indeed, a theoretical model of institutions which considers not just economic phenomena like firms and markets, but which also includes other more explicitly social factors like political parties or even trade unions, suggests that the implicit teleological assumptions of institutional 'convergence' are at best premature and at worst, highly ethnocentric (Beeson 1996). The assumption that economic development would inevitably generate specific forms of social or political development was, therefore, always questionable, but in the wake of the crisis and the profound dislocation it has caused, it looks even more unlikely. Indeed, it should be emphasised that the crisis has caused a deterioration in the strategic environment which has exacerbated tensions both within the region, and between East Asia and the US, which is widely seen as the guiding hand behind the IMF's painful reform measures (Higgott 1998; Dibb et al 1998)

These issues will be considered in more detail below, but it is worth emphasising here that the dramatic changes within the region may have actually made APEC-style reform more, rather than less difficult. When institutions are considered as the products of specific trajectories of national development, rather than as universal and neutral reflections of increasing economic efficiency, it becomes apparent that there are both substantial variations in national institutional forms, and potential obstacles to convergence (Zysman 1994). Where such formations are deeply embedded in and supported by national social and political structures they are neither likely to be easily changed nor seamlessly integrated into transnational organisations. It is precisely this possibility - and the limitations of APEC-led reform - that appears to have informed the IMF approach and accounted for its prominence in the management of the current crisis. To gain a clearer understanding of the different approaches taken to institutional development by APEC and the IMF, it is helpful to consider the distinctive contribution to institutional theory in the political science literature. 
At the heart of March and Olsen's (1984) influential conception of the new institutionalism was an insistence that political institutions had assumed a 'more autonomous' role which needed to be theoretically acknowledged. In their formulation, institutions became 'political actors' in their own right, having the power to independently 'affect the flow of history'. In other words, once created, institutions took on a life of their own, influencing and shaping their environment in unpredictable ways; ways that may not have been intended by their original sponsors. The end of the Cold War combined with the decline of both super-power rivalry and the dominant position of the superpowers themselves, has led to increased attention being paid to the role of international institutions and the possibility of enhanced trans-national cooperation. As Keohane (1984: 246) put it fifteen years ago, 'when we think about cooperation after hegemony, we need to think about institutions'.

Yet even if the increased importance of international cooperation and institution building is accepted, what is noteworthy about some of the influential perspectives emerging from North America in particular has been the restricted depiction of what institutions actually entail. At one level this has been manifest in the 'remarkable' neglect of the domestic bases of national foreign policies (Milner 1992: 481). The theoretical parsimony of systemic theory is achieved at the cost of reducing national domestic politics to little more than a cipher, something that causes differences in national forms of social and economic organisation to be understated and neglected. But this is a reflection of a more fundamental commitment to a methodology that is inherently teleological and which draws much of its theoretical inspiration from the same principles as the more overtly economic institutionalists, like Williamson. International institutions in this view are mechanisms through which rational governments may cooperate to reduce transaction costs and thus further their own selfinterests (Keohane 1984). There is little recognition that the concept of rationality may be highly contingent, ${ }^{4}$ or that the interests which national governments pursue may be fundamentally antagonistic or incommensurate.

Keohane's (1989: 166) influential view of international institution building is predicated upon the assumption that there are 'considerable benefits to be secured from international agreement'. Superficially, this may seem an uncontroversial observation. 
Surely, nations would not cooperate unless there was some tangible benefit to be derived from doing so? Yet it is important to recognise that some nations will inevitably derive more from international agreements than others, while some may have little option than other to cooperate with more powerful nations, even where there appears to be little immediate benefit from doing so. While APEC, as we shall see, may indeed be predicated upon a rationale that assumes mutual benefits from cooperation, the approach of the IMF suggests that there is also a widespread perception that an international political and economic environment currently exists that allows powerful actors to try and impose a particular order on East Asia with comparatively little cost or resistance.

The methodology and language of rational choice theory and the new institutionalism appealed to both political scientists in search of theoretical parsimony and 'scientific' rigour, and to policymakers in search of a coherent formulae with which to promote economic and even social development. When such abstractions were translated into specific 'structural adjustment' policies by influential organisations like the World Bank, the implicit liberal predicates of such policies had a direct impact on local political structures and social formations (Williams and Young 1994). In other words, although the World Bank approach was predicated upon a view of institution building that was essentially positive and in the supposed long-term self-interest of its clients, it has been able - like the IMF - to reinforce its normative reform agenda with direct economic leverage. Interestingly, however, the World Bank has, particularly in the wake of massive, crisis-induced social dislocation throughout Southeast Asia, adopted a less doctrinaire approach to economic reconstruction (Berger and Beeson 1998), highlighting the rift that has emerged between it and the IMF and about the best method of resolving the crisis.

Such differences of opinion suggest that the ascendancy of the Anglo-American reformist paradigm is not grounded in superior technique or problem solving capacity. On the contrary, the influence of market-oriented reform policies owes a good deal to the sorts of overt economic leverage available to powerful transnational organisations in enforcing a specific set of economic practices and ideational norms ( Gill 1993). It is essentially a political project, increasingly informed by the theoretical precepts of neoclassical economics in general and the transaction cost economics in particular. 
Central to the prescriptive injunctions of these Anglo-American oriented agencies is an implicitly teleological view of economic development, in which the institutions that govern and shape economic activity become progressively more efficient.

And yet for all the direct economic and political reformist pressure that the nations of East Asia are currently experiencing, it is not at all clear that the economies of East Asia will 'converge' on the Anglo-American model. The distinctive patterns of political and economic organisation that have emerged throughout East Asia have developed through a process of historical accretion, and are likely to prove resistant to the sorts of teleological rationality implicit in much institutional literature. There is, however, a branch of institutional theory which not only takes historical processes seriously, but which provides a way of comprehending the different institutional forms that result. The next section considers both this theoretical perspective and the sorts of historically specific analyses it has generated.

\section{Historical institutionalism and the persistence of difference}

'Historical' institutionalists adopt a more comprehensive formulation than those considered hitherto. Institutions are taken to be more complex entities, embracing 'the formal and informal procedures, routines, norms and conventions embedded in the organisational structure of the polity or political economy' (Hall and Taylor 1996: 938). In this wider conception, institutions are not theoretically limited to discrete phenomenon like firms, for example, but expanded to capture the influence of the broader historical and social milieu from which they emerge. A consideration of the national context within which institutions are embedded, with all the historical specificity that implies, provides a more persuasive account of the persistent differences that continue to characterise notionally similar institutions across nations. It is precisely this sort of analysis that is missing in many of the more narrowly defined readings of institutions that inform not just influential and predominantly north American brands of theorisation, but also provides the underpinning logic for APEC's approach to institutional reform. 
Rather than the rational pursuit of economic outcomes, an historical institutional analysis suggests that economic policy is necessarily political and the outcome of enduring processes. One of Peter Hall's (1986: 19-21) most important and persuasive contentions is that the different economic policies pursued by individual nations are not simply determined by prevailing economic conditions, but are shaped by contingent political and organisational dynamics. The particular accommodations reached between capital, labour and national governments not only display a good deal of variation across nations, but such variations are ultimately institutionalised in distinctive patterns of authority relations, rules, and social practices that distinguish one polity from another. Moreover, contemporary relationships between economic and political actors are affected by the institutional memory of previous accommodations. In other words, political relations and economic structures are not infinitely malleable and capable of easily responding rationally to shifting patterns of incentives, but path dependent structures reflective of existent and historically entrenched social relations.

The importance of such theoretical considerations is especially apparent in East Asia. An historically informed brand of institutionalism is particularly relevant at a number of interconnected levels of analysis. First, the developmental trajectories and national accommodations reached within the Asian part of the 'Asia-Pacific region' have been shaped by the larger international context of which they are a part. As Stubbs (1994) points out, the US's strategic interests during the Cold War provided a crucial spur to East Asia's economic development. Aid and military spending provided an important stimulus for economic expansion, whilst simultaneously consolidating and legitimising state structures and the specific institutionalised patterns they assumed. The US's strategic dominance of East Asia and its unilateral approach meant that "the capitalist countries of the region tended to communicate with one another through the United States' (Cumings 1997: 155 [emphasis in original]). Consequently, there is little tradition of multilateral relations for a new organisation like APEC to build on.

Recognition of the enduring and distinctive patterns of national institutional consolidation is especially important in an East Asian region which was, until recently at least, synonymous with the 'developmental state' (Johnson 1982). While Japan's current economic problems and the crisis more generally have raised long-term 
questions about the viability of the Northeast Asian interventionist model (Beeson forthcoming a), it is important to remember quite how widespread the developmental, dirigiste model became throughout the region (Wade 1990; Castells 1992). Not only did states adopt policies at odds with the minimalist, non-interventionist, marketoriented ideal posited in Anglo-American economic orthodoxy and embodied in APEC's reform agenda, but this alternative state-led developmental model became structurally embedded in institutionalised distributional coalitions throughout the region. It was the recognition of precisely this sort of potential obstruction to neoliberal reform that has, by contrast, made the IMF's reforms so detailed, specific and binding in countries like Indonesia (Robison and Rosser 1998).

An even more obdurate impediment to neoliberal reform and the emergence of ubiquitous economic practices and structures is evident at the level of the firm or business organisation. Once again, Japan has played a particularly important role in defining a type of capitalist organisation that has predominated in East Asia, both as an exemplar and increasingly as the centre of region-wide networks of production and distribution. Japan is especially significant here as not only does it have a highly distinctive corporate structure embodied in the keiretsu networks of inter-connected companies (Gerlach 1992), but it has systematically exported this structure across the East Asian region as Japanese corporations have responded to international competitive pressures and opportunities and moved off-shore (Hatch and Yamamura 1996). As elements of these distinctive forms of corporate organisation have been exported, they have integrated neighbouring economies into hierarchically organised production structures with their apex in Japan. Moreover, these evolving regional production networks have been systematically institutionalised and entrenched by a complex array of political connections, economic assistance packages and trade agreements that have made their modification by market-oriented policy initiatives inherently problematic. Rather than benefiting from and responding to the sorts of enhanced market signals that an APEC-led liberalised trading environment might provide, Japanese companies have developed 'glocalisation' strategies that actually take advantage of market 'distortions' and host government incentives (Ruigrok and van Tulder 1995: 192). 
Another distinctive element of East Asian political-economy that merits brief mention as an example of historically embedded institutions that may well prove equally impervious to rapid or wholesale change are the business practices associated with the so-called 'overseas Chinese'. Particularly important in this regard are the political connections established between large-scale Chinese capitalists and political elites in a number of countries like Thailand, Malaysia and Indonesia (Beeson forthcoming b). The point to make here is that, despite the traumas being experienced by ethnic Chinese communities in Indonesia, relationship-based (gaunxi) business practices are not only unlikely to disappear, but are likely to provide an enduring obstacle to the achievement of 'transparent' economic relations of the sort being encouraged by APEC and imposed by the IMF.

There are, then, a range of deep-seated patterns of institutionalised organisation in East Asia, at the level of the inter-state system, the nation and the firm, which have shaped national accommodations and which may prove resistant to rapid modification. To understand the potential significance of these structural resistances it is important to look more closely at the different approaches taken by the key inter-governmental organisations intent on achieving institutional reform in the region. In what follows, I shall focus mainly on APEC, as it is a revealing embodiment of influential ideas from North American economics and political science, ideas which appear to have been of little theoretical or pragmatic utility in the current crisis.

\section{The Competing Approaches to Reform of APEC and the IMF}

Having considered some of the more influential theories of institutions, I shall now examine the different approaches of APEC and the IMF to actually reforming or reshaping institutions throughout East Asia in particular. Again, let me emphasise that it is not being suggested that there is a direct causal relationship between theory and practice. What we can say, however, is that certain ideas have provided an influential backdrop for certain policy initiatives - especially in the case of APEC - and that, at the very least, reviewing the experiences of these important organisations a useful way of evaluating theoretical ideas more generally. 


\section{APEC's institutional evolution}

The story of APEC's origins and consolidation helps illuminate some of the tensions and contradictions that threaten to undermine the unproblematic developmental trajectories implicit in much institutional theorisation. Two factors are especially germane in this regard: the disparate purposes that originally underpinned individual nation's support for APEC, and the way in which such divergent national purposes and perspectives have coalesced into sharply differentiated views about APEC's present role, its future, and its place in the region. Although neoliberal reform of the sort championed by APEC has never before been as prominent in the region, it should be reemphasised at the outset that this is being imposed upon an East Asian region with little history of or enthusiasm for such reforms. APEC's near invisibility during the crisis suggests that its preferred mode of voluntarism and consensually determined, cooperatively achieved policy outcomes is incapable of achieving similar results.

Yet the desire to systematically promote some form of regional cooperation in the 'Asia-Pacific' - at least at the non-governmental level - is at least eighty years old (Woods 1993: 33). Despite the long-standing nature of this ambition, APEC's comparatively recent inauguration has led some observers to conclude that a new and compelling nexus currently exists between changing economic circumstances and the development of a concomitant political momentum toward regional institution building (Drysdale 1988). Indeed, this sort of analysis often betrays a distinctly functionalist tenor, depicting the emergence of APEC as a response to a 'fundamental need' in the region for a 'structure of certainty' (Dobson \& Lee 1994: 231). It is a view that is in sympathy with and draws theoretical support from certain forms of institutional theory, and given explicit articulation by influential supporters in terms of transaction cost logic (Elek 1995).

A couple of initial caveats about these sorts of seamless visions are in order, however. First, although it is commonplace to refer to an 'Asia-Pacific region', it needs to be remembered that the 'region' which APEC seeks to integrate politically and 
economically is essentially a discursive construction of relatively recent origin (Dirlik 1992). This is not simply a semantic point; one of APEC's enduring problems has been deciding quite who is eligible for membership. Second, APEC's highly disparate membership contains not only a wide range of political and economic formations, ${ }^{5}$ but also potentially incommensurate views about the purpose and character of the organisation itself. Indeed, the potential limitations of the APEC approach - especially as far as the US was concerned - and its relative insignificance as a mechanism for achieving fundamental economic reform in East Asia was revealed by the decision to accept Russia as a new member. Clearly, the US was prepared to sacrifice APEC's coherence and identity in pursuit of its own wider strategic interests, which continue to centre on Europe rather than the Asia Pacific (Kelly 1997).

While the US may be the most important and dramatic illustration of a clash between domestic priorities and commitment to the sorts of international cooperative activities that influential strands of institutional theory suggest are becoming more common, it is hardly unique. Indeed, it is important to recognise that even for the original sponsors of APEC - Australia and Japan - there was a finely grained perception of a national interest, the pursuit of which might be most effectively realised through transnational mechanisms. The story of the development of economic cooperation in the Asia Pacific in general and of APEC's evolution in particular are by now well enough known to require little repetition here (Soesastro 1994; Funabashi 1995). What does merit emphasis is that Japan's initial proposal for a Pacific free trade area was both driven and frustrated by a predominantly political calculus of national self-interest, rather than some universal pursuit of economic rationality (Kerhonen 1994).

Rather than being the result of the rational pursuit of increasingly efficient institutional mechanisms with which to govern economic activity, Yoichi Funabashi (1995: 105) contends that Japan's (and Australia's, for that matter) principal motivation in promoting APEC in the late 1980s was 'fear'. Concern about possible American isolationism, protectionism and the breakdown of the global trading system into competing economic blocs provided powerful incentives for supporting a regional trade grouping that was not only centred on the Pacific, but which had the crucially important participation of the US. ${ }^{6}$ In this regard, Japan's relationship with the US is just the most 
important exemplar of a region wide imperative: maintaining access to a critically important market without which East Asia's rapid economic development would not only have been more difficult in the past, but which might be less assured in the future (Bello and Rosenfeld 1990).

Similarly in Australia, although policy was influenced by a coterie of economic advisers who subscribed to the predominantly Anglo-American, market-oriented orthodoxy, the strategic and economic reorientation toward Asia owed a good deal to changing political circumstance. A diminished commitment toward multilateral principles, especially on the part of important allies like the US, made the need to establish 'insider' status in some form of regional trade grouping all the more urgent. In short, as Australia's trade and investment became increasingly focused on East Asia, the region assumed an importance that made Australia's possible exclusion unthinkable.

Both APEC's institutional form and the content of its economic reform agenda reflect the interests and influence of its disparate membership. While there may be nothing remarkable about such an observation, it merits repeating as it at odds with the assumptions of universal political and economic rationality that distinguish mainstream institutional theory. One of the more important initial (and continuing) obstacles to APEC's formal institutionalisation was a concern, especially on the part of the countries of the Association of Southeast Asian Nations (ASEAN), that APEC as an institution should remain of limited size, influence and scope (Ariff 1994). There was, and is, considerable nervousness on the part of some members that APEC may institutionalise not just binding rules and regulations to govern regional commerce, but entrench the asymmetries of power that characterise its diverse membership.

Within APEC's membership, therefore, there are major differences of opinion regarding the way the organisation should develop and the range of issues over which it might claim authority. These views are informed by and reflective of the different political and economic formations, which are themselves the product of enduring historical processes (Beeson and Jayasuriya 1998). These differences are not captured in analyses that rely on highly abstract formulations that neglect national individuation and historical specificity. Even at the most broad brush level there are clearly important and enduring 
differences in the way political and economic systems are organised amongst APEC's Anglo-American members as opposed to their counterparts in East Asia. APEC's future evolution will therefore be determined by the way such divergent practices are accommodated and negotiated.

\section{APEC and institutional reform}

The policy agendas of both APEC and the IMF are closely aligned with so-called 'Washington Consensus' of fiscal discipline, privatisation, financial and trade liberalisation, openness to investment, deregulation and a general concern with increasing the 'transparency' of economic and political processes (Williamson 1994). What distinguishes them, of course, is the way they set about achieving it. Central to both these organisations' essentially neoliberal reform agendas, however, is the desire to reshape regional institutions so that they more closely reflect market principles and allow such mechanisms to work optimally. Again, APEC's pre-crisis strategy for achieving this goal reflects a range of theoretical influences that now seem somewhat anachronistic, and which are, in any case, increasingly at odds with the approach taken by the IMF.

The Eminent Persons Group (EPG), created at APEC's fourth ministerial meeting in 1992, was charged with developing a vision for Asia-Pacific trade relations to the year 2000. Despite the generally 'pro-business' orientation of the $\mathrm{EPG}^{7}{ }^{7}$ it has found it difficult to accommodate easily the differing interests and positions of member countries, something that has been reflected in much APEC-related discourse. The notion of 'open-regionalism' - or a non-binding commitment to non-discriminatory trade liberalisation - is a good example of the sort of compromise the competing forces within APEC necessitates. On the one hand this notion is indicative of the influence of key academic economists concerned to reduce transaction costs through the removal of trade barriers (see Drysdale and Garnaut 1993), yet at the same time the notion is sufficiently imprecise, open-ended and non-binding as to pose little real threat to vested interests or existing patterns of political and economic organisation in the 
region. Only by adopting such ambiguous language was it possible to accommodate the disparate positions amongst APEC's members.

The EPG (1994: 30) report was forced to advocate seemingly contradictory positions on trade deregulation, simultaneously advocating both unilateral and reciprocal liberalisation. This latter concession reflects the influence of the US and its desire to use APEC as a mechanism to both prize open Asian markets and to put pressure on other trade groupings like the European Union to lower trade barriers - the US only became enthusiastic about APEC because of its potential as a bargaining chip against the (then) European Community in the final stages of the Uruguay Round (Ravenhill 1995: 194). From the outset, in fact, the US has had a very different approach to APEC than many of its other members.

Fred Bergsten (1994), the US representative in the EPG, sees APEC as principally a mechanism for 'ratcheting up trade liberalisation', something that might, if successful, be expected to overcome the US's chronic and increasing trade deficit with APEC's Asian members by prizing open what generally remain highly protected markets. ${ }^{8}$ The approach of the US in general and Bergsten in particular is one that reflects wider American norms and practices, and finds expression in the promotion of rule-based agreements which reduce the possibility of what Bergsten describes as a 'continued resort to unilateral measures' (Ito 1995). The desire to lock APEC members into a legalistic framework that would establish binding regulations for the conduct of trade, and deadlines by which such agreements must be implemented, is clearly something that alarms many of APEC's Asian members (Garran 1995). It as an approach that it is at odds with the consensus-based, 'Asian way' that has characterised organisations like ASEAN. More fundamentally, the US-led legalistic approach fails to recognise that the legal system in East Asia is utilised not so much to restrain the state but, as Jayasuriya (1996) observes, deployed as an important instrument of state rule. In other words, the assumptions of political rationality and the separation of powers that underpin influential theoretical Anglo-American discourses are simply not relevant in an East Asian context. 
There are other issues apart from possibly incompatible legal and political traditions, that made East Asia reluctant to embrace neoliberal reform before the crisis, and which may shape future policy developments in the region. The most prominent opponent of Anglo-American style reforms both before and since the crisis has been Malaysian Prime Minister Mahathir Mohamad. Mahathir's concerns are centred on the fear that 'the South' may continue to be economically dominated by 'the North' (Stewart 1996). While the language may be reminiscent of the dependency theorists of the 1960s, it reflects a continuing uneasiness about both the impact of unbridled neoliberal reform and the potential that rule-based economic governance has for undermining institutionalised distributional coalitions throughout the region. Much of this antipathy to neoliberal reform and the imposition of more transparent economic and political practices can be explained by recognising that the Malaysian political-economy bears little resemblance to the idealised picture depicted in much institutional theory with its conceptual differentiation between the state and business. On the contrary, the state, or more particularly the ruling United Malays' National Organisation (UMNO) which dominates Malaysia's political system, is deeply involved in business activity in Malaysia (Gomez 1995).

Malaysia is representative of a number of long standing vested interests across the region that might be seriously damaged by the sorts of transparent commercial practices and deregulated economic activities that APEC's reform agenda proposes. ${ }^{9}$ There is little to suggest that the sorts of incentive structures mooted in rational choice based institutional theory will have much applicability in nations where the distinction between political and economic spheres is blurred, and where the response to the apparently universal imperatives of international economic restructuring has until recently been mediated largely within the confines of the state (Jayasuriya 1995). More fundamentally, it is not impossible that the sorts of issues that Mahathir identifies will gain a wider audience in the region if the crisis drags on and orthodox prescriptions fail to work. After all, while Mahathir may be primarily concerned with political survival, he does identify enduring about the sovereignty of states and the right to pursue autonomous, state-led economic development in the way that all of the early industrialising nations did (Landes 1998: 265-6). In other words, resistance to the APEC agenda was not predicted exclusively on maintaining a 'crony capitalist' status quo - 
although that may be important - but on more enduring questions about the validity of state-centred economic developmentalism.

It is precisely the embedded and institutionalised relationships, and the economic and political practices that are associated with them, that are inherent to the East Asian developmental states and which the IMF has sought to target in its attempts to impose neoliberalism throughout the region.

\section{The IMF's approach to institutional reform}

If APEC's attempts to promote market-centred neoliberal reform have been centred on moral suasion and voluntarism, the IMF's has approach has been altogether more forceful and coercive. While both organisations may share the view that the development of appropriate economic policy is ultimately a 'technical' matter, the IMF has been presented with a possibly unique historical opportunity to systematically impose its preferred policy vision upon a number of countries with little power to resist. In order to understand why the IMF finds itself in such a uniquely powerful position in the region, and why it is attempting to impose specific sorts of reforms, it is helpful to sketch briefly its own institutional evolution and place in the international system.

Although the story of the emergence of the Bretton Woods system - of which the IMF was a key element - is well enough known to need little repetition here, it is worth stressing just how remarkable a change has occurred not only to the overall Bretton Woods system itself, but also in the role of bodies like the IMF. ${ }^{10}$ The rationale that underpinned what Ruggie (1982) famously described as the compromise of embedded liberalism, in which countries retained a degree of domestic policy autonomy within an open international economic system, has been overturned as the barriers between the national and international spheres have become increasingly porous.

The IMF's own evolution has mirrored this wider systemic change. From being an institution charged with maintaining equilibrium within an essentially regulated international system in which fixed exchange rates and regulated financial sectors were 
central components, the IMF has now become the principle instrument for eliminating such restrictions and imposing an open, liberalised economic order with fewer restrictions on the movement of capital. Significantly, when the IMF was reconstituted in the 1970 s to accommodate an increasingly liberalised international financial system, states 'formalised their commitment to the principle of multilateral oversight' (Pauly 1997: 38). It is precisely this surveillance capacity, critics contend, that is associated with the imposition of a form of 'disciplinary neoliberalism' (Gill 1997), something which effectively de-legitimises East Asian styles of economic development. Indeed, it should be emphasised that whereas the architects of the original post-war Bretton Woods order saw unrestrained market forces as potentially dangerous, destructive and intimately associated with the Depression, market forces are now viewed by the IMF as having the capacity to 'exert a disciplining influence on countries' macroeconomic policies' (Fischer 1997: 3).

The idea that financial liberalisation might be an instrument of disciplinary power, rather than the rationally chosen solution to a specific economic problem, is revealing enough in itself. However, it is the IMF's close alignment with the US and its foreign policy goals that has raised important questions about the IMF's 'rescue' packages in particular and about the general course of inter-regional relations more generally. Indeed, the IMF's own institutional evolution, structure and relations with the US suggest that the consolidation of a market-centred economic order in the Asia-Pacific or more specifically, East Asia - is anything but an illustration of cooperative behaviour in pursuit of positive sum games. On the contrary, as the testimony of US Trade Representative Charlane Barshefsky graphically revealed, the IMF reform packages for East Asia will 'complement and reinforce our trade policy goals' (cited in Bullard et al 1998: 123).

Not only does the US retain veto power and major influence over the IMF's overall policy direction (Rapkin et al 1997), but the 'rescue packages' being implemented in the troubled economies in East Asia contain such specific requirements of recipients so as to fundamentally restructure their domestic political economies. Whatever the 'technical' merits of the IMF packages, there is clearly no doubt that - if fully implemented - they would transform the structure of economies which the US has been 
unsuccessfully attempting to reform for a number of years. In other words, in the current environment in which the East Asian region finds itself in a highly vulnerable position, attempts to reconfigure domestic political and economic systems seem to owe more to the power-centred perspective of Samuel Huntington (1993) than they do to Keohane's cooperative and enlightened institution building schema considered earlier.

Although the principle interest here is not in dissecting the possible merits of IMF policies, it is necessary to make a few brief comments about the detail of the reforms it has developed for the region as they have been subjected to a number of cogent and revealing criticisms. ${ }^{11}$ The most important point to highlight is what the IMF (1998:2) itself calls the 'far-reaching structural reforms at the heart of all the programs'. In Indonesia, for example, the IMF has insisted on a detailed range of changes to the banking sector (including wholesale closures), privatisation programs, the abolition of monopolies and a range of measures that effectively break open existing centres of economic power and control (Jakarta Post, January 17, 1998: 5). Again, it is not necessary to establish whether or not these are useful measures on technical efficiency grounds, to recognise that they are profoundly threatening to the existing order and go much further than any measures undertaken in other comparable crises. ${ }^{12}$ Similarly, the reforms being demanded of South Korea are sufficiently comprehensive and demanding as to effectively spell the end of the Korean high-debt model of economic expansion (Ministry of Finance and Economy, 1997). ${ }^{13}$

Two key points emerge from this overview of the IMF's recent activities. First, the IMF approach not only stands in stark contrast to that of APEC, but it is an effective refutation of the logic that underpins much influential, predominantly North American scholarship. Clearly, the IMF's systematic attempts to dismantle the central structures of East Asian capitalism and impose a 'level playing field' in the region have little to do with the enlightened, cooperative pursuit of reducing transaction costs, and everything to do with the application of economic and political leverage in a post-Cold War environment in which the US can privilege domestic interests unconstrained by strategic considerations (Ruggie 1996). 
Second, it is not necessary to defend authoritarian rule or 'crony capitalism' to acknowledge that the currently parlous condition of countries like Indonesia has as much to do with the activities of highly mobile financial capital and a reconfigured international political economy as it does with any strictly domestic issues (Beeson 1998). When even orthodox economists have criticised the IMF's approach and drawn attention to an IMF-Wall Street-Treasury complex that appears to favour the interests of rentier capitalists in the US despite the potential damage further financial liberalisation may cause to East Asian economies (Bhagwati 1998), then the preconditions for entrenching what Richard Higgott (1998) calls the 'politics of resentment' are clearly in place, making APEC-led cooperatively determined outcomes increasingly implausible.

\section{Concluding Remarks}

The roles played by APEC and the IMF in the wake of the crisis could hardly be more different. When confronted by its first major test, APEC has been revealed to be ineffectual at best and completely irrelevant at worst. The IMF, by contrast, has played a prominent and at times decisive role in influencing the trajectory of the crisis itself and in reshaping regional institutions in its aftermath. This is not meant to imply that the IMF's policy prescriptions were in some way 'correct' or appropriate in a way that APEC's were not, however. On the contrary, there is every reason to think that the IMF's insistence on fiscal austerity and increased liberalisation may actually have exacerbated an already perilous economic position. The point to emphasise is that the IMF did not need to rely on moral suasion or achieve consensus about the direction and content of regional public policy to achieve its aims. In short, the IMF's application of direct political and economic leverage has proved a far more efficacious route to regional institutional reform than has APEC's voluntarist approach.

Although most attention has understandably focused on the unfolding dynamics of crisis management, the crisis has also highlighted a number of important theoretical issues. APEC's conspicuous absence and inability to play a meaningful role during the crisis suggests that the sorts of theoretical assumptions that informed its policy style and 
rationale are incapable of either explaining the crisis itself or of providing a useful template for future policy. It is important to recognise that the institutional change that is occurring in East Asia is not the triumph of good policy over bad, or ill-informed Asians finally recognising the error of their ways and rationally opting for a technically optimal, neo-liberal economic paradigm. While there may be 'technocrats' sympathetic to Anglo-American forms of economic organisation throughout the region, the principal engine of change is a combination of external pressure and a diminishing capacity for domestic resistance. The IMF's policies are significant in this regard as they implicitly recognise the importance of embedded institutions as a potential obstacles to change in the region. This is not to suggest that IMF or Treasury Department officials have been diligently reading a variant of institutional theory that takes historical specificity seriously and acting upon its insights, but to suggest that some variants of institutional theory offer much more plausible readings of institutional change in the region than others.

Historically grounded institutional theory reminds us that the current struggle to shape the institutional infrastructure that will constrain and determine the course of the region's evolution will inevitably be a political one that reflects the relative strengths of key actors within the region, rather than being an expression of inherent rationality or simply the desire to reduce transaction costs. Consequently, we may find that not only will the efforts of the IMF to impose a neoliberal reform agenda on the region be resisted, but that the practical and theoretical challenges thrown up by the crisis will force a similar reassessment of neoliberal reform itself. As the international economic system teeters on the brink of recession if not depression, there are grounds for supposing that the current difficulties facing the region may be as much to do with capitalism in general, rather than its East Asian manifestations in particular. In such circumstances, a revaluation of the structure of Anglo-American economic institutions and the theoretical assumptions that underpin them looks equally timely.

\section{Acknowledgments}

An earlier version of this paper was presented at the International Studies Association conference in Toronto, 1997. I would like to thank Mark Berger, Richard Higgott, Jane 
Hutchison and Kanishka Jayasuriya for reading and commenting on earlier drafts. The usual caveats apply. Finally, I would like to acknowledge the role of the Asia Research Centre, Murdoch University in supporting this research.

\section{References}

APEC Secretariat (1995) Selected APEC Documents, Singapore: APEC.

Ariff, M. (1994) 'The role of APEC: An Asian perspective', Journal of Japanese Trade and Industry, 13 (1): 46-9.

Beeson, M. (1996) 'Asia's disparate political economies and the prospects for transnational "convergence", Asian Journal of Public Administration, 18 (2) : 141-67.

-(1998) 'Indonesia, the East Asian crisis, and the commodification of the nation-state', New Political Ecor

-(forthcoming a) 'The end of the miracle? Japan and the East Asian crisis', Political Science.

_forthcoming b) 'The political-economy of East Asia at a time of crisis', in Richard Stubbs and Geoffrey

Beeson, M. and Jayasuriya, K. (1998) 'The political rationalities of regionalism: APEC and the EU in comparative perspective', The Pacific Review, 11 (3): 311-36.

Bello, W and Rosenfeld, S (1990) Dragons in Distress: Asia's Miracle Economies in Crisis, London: Penguin Books.

Berger, M. and Beeson, M. (1998) 'Lineages of liberalism and miracles of modernization: The World Bank, the East Asian trajectory and the international development debate', Third World Quarterly, 19 (3): 487-504

Berger, P. L. and Luckmann, T. (1971) The Social Construction of Reality: A Treatise on the Sociology of Knowledge, London: Penguin Books. 
Bergsten, C.F. (1994) 'APEC and world trade: a force for worldwide liberalisation', Foreign Affairs, 73 (3): 20-26.

Block, F.L. (1977) The Origins of International Economic Disorder, (Berkeley: University of California Press.

Bullard, N. et al (1998) 'Taming the tigers: The IMF and the Asian crisis', in Jomo, K.S. (ed.), Tigers in Trouble: Financial Governance, Liberalisation and Crises in East Asia, London: Zed Books: 85-136.

Castells, M. (1992) 'Four Asian tigers with a dragon head: a comparative analysis of the state, economy, and society in the Asian pacific Rim, in Appelbaum, R.P. \& Henderson, J. (eds) States and Development in the Asian Pacific Rim, Newbury Park: Sage, pp 3370.

CEDA (Committee for Economic Development of Australia, 1995) APEC and Australian Business: Evaluating the Opportunities Targeting Impediments to Trade, Sydney: CEDA.

Dibb, P. et al (1998) 'The strategic implications of Asia's economic crisis', Survival, 40 (2): 5-26.

Dirlik, A (1992) 'The Asia-Pacific idea: reality and representation in the invention of regional structure', Journal of World History, 3 (1): 55-79.

Dobson, W \& Lee Tsao Yuan (1994) 'APEC: Co-operation amidst Diversity', ASEAN Economic Bulletin, 10 (3) : 231-44.

Drysdale, P. (1988) International Economic Pluralism: Economic Policy in East Asia and the Pacific, Sydney: Allen \& Unwin.

Drysdale, P. and Garnaut, R. (1993) 'The Pacific: An application of a general theory of economic integration', in Bergsten, C.F. and Noland, M. (eds.), Pacific Dynamism and 
the International Economic System, Washington: Institute of International Economics: 183-223.

Eminent Persons Group (1993) A Vision for APEC: Towards and Asia Pacific Economic Community, Singapore: Asia-Pacific Economic Cooperation.

Elek, A (1995) 'APEC beyond Bogor: an open economic association in the AsainPacific region', Asian-Pacifc Economic Literature, 9 (1): 1-16.

Funabashi, Y. (1995) Asia Pacific Fusion: Japan's Role in the APEC, Washington: Institute for International Economics.

Garran, R. (1995) 'Asians 'concerned' by APEC deadlines', The Weekend Australian, 25-26 February: 14.

Gerlach, M. (1992) Alliance Capitalism: The Social Organization of Japanese Business, University of California Press, Berkeley.

Gill, S. (1993) 'Neo-liberalism and the Shift Towards a US-centred Transnational Hegemony', in Henk Overbeek (ed) Restructuring Hegemony in the Global Political Economy: The Rise of Transnational Neo-liberalism in the 1980s, London: Routledge: 246-82.

- (1997) 'Finance, production and panopticism: inequality, risk and resistance in an era of disciplinary neo-liberalism', in Gill, S (ed) Globalization, Democratization and Multilateralism, London: Macmillan: 51-75

Gilpin, R. (1987) The Political Economy of International Relations, Princeton: Princeton University Press.

Goldstein, J \& Keohane, R O (1993) 'Ideas and Foreign Policy: An Analytical Framework', in Goldstein, J \& Keohane, R O (eds) Ideas and Foreign Policy: Beliefs, Institutions and Political Change, Ithaca: Cornell University Press: 3-30. 
Gomez, E.T. (1994) Political Business: Corporate Involvement of Malaysian Political Parties, Townsville: James Cook University.

Hall, P. (1986) Governing the Economy: The Politics of State Intervention in Britain and France, Oxford: Oxford University Press.

Hall. P. A. and Taylor, R.C.R. (1996) 'Political science and the three new institutionalisms', Political Studies, 44: 936-57.

Hatch, W. and Yamamura, K. (1996) Asia in Japan's Embrace: Building a Regional Production Alliance, Cambridge: Cambridge University Press.

Higgott, R. (1998) 'The Asian economic crisis: A study in the politics of resentment', New Political Economy, 3 (3).

Huntington, S.P. (1993) 'Why internatinal primacy matters', International Security, 17 (4): 68-83.

— (1996) The Clash of Civilizations and the Remaking of World Order, New York: Simon \& Schuster.

Higgott, R. et al (1990) 'Asia-Pacific Economc Cooperation: An evolvinbg case-study in leadership and co-operation building', International Journal, 45: 823-66.

Fischer, S. (1997) 'Capital account liberalization and the role of the IMF', IMF Seminar: Asia and the IMF, September 19. http://www.imf.org/external/np/speeches/1997/0911997.htm

IMF (1998) The IMF's Response to the Asian Crisis, IMF: http://www.imf.org/External/np/exr/facts/asia.HTM 
Ito, S. (1995) 'US backs APEC to mediate on trade', The Weekend Australian, 8-9 July: 17.

Jayasuriya, K. (1996) 'The rule of law and capitalism in East Asia', The Pacific Review, 9 (3): $367-88$.

Johnson, C. (1982) MITI and the Japanese Miracle: The Growth of Industry Policy 1925-1975, Stanford: Stanford University Press.

Keohane, R.O. (1984) After Hegemony: Cooperation and Discord in the World Political Economy, Princeton: Princeton University Press.

-(1989) International Institutions and State Power: Essays in International Relations Theory, Boulder: We:

Kelly, P. (1997) 'US imperatives rule in maturing APEC', The Australian, November 27.

Korhonen, P. (1994) Japan and the Pacific free Trade Area, London: Routledge.

Landes, D.S. (1998) The Wealth and Poverty of Nations: Why Some Are So Rich and Some So Poor, New York: W.W. Norton.

Lane, R.E. (1991) The Market Experience, Cambridge: Cambridge University Press.

Leys, C. (1996) 'Rational choice or Hobson's choice? The "new political economy" as development theory', Studies in Political Economy, 49, Spring: 37-69.

Mayhew, A. (1987) 'Culture: core concept under attack', Journal of Economic Issues, 21 (2): 587-603.

Milner, H. (1992) ' International theories of cooperation among nations: Strengths and weaknesses', World Politics, 44, (3): 466-96. 
Ministry of Fiance and the Economy (1997) 'The IMF Program: Comprehensive Implementation Action and Plans (Summary)', Seoul:

http://kiep.go.kr/IMF/hot-2.html

North, D.C. (1990a) Institutions, Institutional Change and Economic Performance, Cambridge: Cambridge University Press.

- (1990b) 'Institutions and their consequences for economic performance', in K. S. Cook \& M. Levi (eds) The Limits of Rationality, Chicago: The University of Chicago Press.

—(1994) 'Economic performance through time', The American Economic Review, 84 (3): 359-68.

-(1995) 'The new institutional economics and Third World development', in John Harriss et al, (eds) The

Pauly, L.P. (1997) Who Elected the Bankers? Surveillance and Control in the World Economy, Ithaca: Cornell University Press.

Radelet, S. and Sachs, J. (1998) The Onset of the Asian Financial Crisis, World Wide Web document, URL: <http://www.stern.nyu.edu/ nroubini/asia/AsiaHomepage.html>

Rapkin, D et al (1997) 'Institional adjustment to changed power distributions: Japan and the United States in the IMF', Global Governance, 3 : 171-95.

Ravenhill, J (1995) 'Competing logics of regionalism in the Asia-Pacific', Journal of European Integration, 18 (2-3): 179-99.

Robison, R. and Rosser, A. (forthcoming) 'Contesting rteform: Indonesia's New Order and the IMF', World Development.

Ruggie, J. G. (1982) 'International regimes, transactions, and change: embedded liberalism in the postwar economic order', International Organization, 36 (2): 379-415. 
— (1996) Winning the Peace: America and World Order in the New Era, New York: Columbia University Press.

Ruigrok, W. and van Tulder, R. (1995) The Logic of International Restructuring, London, Routledge.

Rutherford, M. (1994) Institutions in Economics: The Old and New Institutionalism, Cambridge: Cambridge University Press.

Soesastro, H. (1994) 'Pacific economic cooperation: A historical exploration', in Soesastro, H (ed) Indonesian Perspectives on APEC and Regional Cooperation in Asia Pacific, Jakarta: Centre for Strategic and International Studies.

Stewart, I. (1996) 'Mahathir uses UN speech to attack the West', The Australian, 30 September: 14.

Stubbs, R. (1994) 'The political economy of the Asia-pacific region', in Stubbs, R. \& Underhill, G. (eds) Political Economy and the Changing Global Order, London: Macmillan: 366-77.

Wade, R. (1990) Governing the Market: Economic Theory and the Role of Government in East Asian Industrialization, Princeton: Princeton University Press.

Wade, R. and Veneroso, F. (1998) 'The Asian crisis: The high debt model versus the Wall Street-Treasury-IMF complex', New Left Review, 228: 3-23.

Wendt, A. (1992) 'Anarchy is what states make of it: the social construction of power politics', International Organisation, 46 (2): 391-425.

Williams, D. and Young, T. (1994) 'Governance, the World bank and Liberal Theory', Political Studies, 42: 84-100. 
Williamson, John (1994) 'In Search of a Manual for Technopols'. In J. Williamson

(ed.), The Political Economy of Policy Reform. Washington: Institute for International Economics, pp 11-28.

Williamson, O.E. (1985) The Economic Institutions of Capitalism: Firms, Markets Relational Contracting, New York: The Free Press.

-(1993) 'Transaction cost economics and organisation theory', Industrial and Corporate Change, 2 (2): 10

Woods, L (1993) Asia-Pacific Diplomacy: Nongovernmental Organisations and International Relations, Vancouver: UBC Press.

Zysman, J. (1994) 'How institutions create historically rooted trajectories of growth', Industrial and Corporate Change, 3 (1): 243-83.

\section{Endnotes}

${ }^{1}$ For a more extensive discussion of the differences between rational choice, historical and sociological forms of institutionalism, see, (Hall and Taylor 1996).

2 Mayhew (1987) makes the point that even if it is accepted that definitions of 'rationality' are universally applicable, what are taken to be rational institutions may vary considerably across nations. This is, as we shall see, a potentially serious obstacle for APEC.

${ }^{3}$ As North (1990b) points out, in circumstances where criminal activity guarantees the greatest pay off, then organisational development will reflect such incentives, a suggestion that the contemporary experience of Russia seems to support.

${ }^{4}$ Even the concept of 'bounded rationality' fails to satisfactorily deal with the limited applicability this notion, particularly the dubious assumptions about human motivation and access to information that the idea of rationality entails. For a fuller discussion of these limitations, see, Lane (1991 chapter 3). 
${ }^{5}$ APEC's current membership is: Australia, Brunei, Canada, Chile, China, Hong Kong, Indonesia, Japan, Republic of Korea, Malaysia, Mexico, New Zealand, Papua New Guinea, the Philippines, Singapore, Thailand, the Unites States and Taiwan, or 'Chinese Taipei' as it is known in APEC-speak given Mainland sensitivities about Taiwan's status. Russia, Vietnam, and Peru will join in 1998. Comprehensive profiles of the APEC membership's very different economies are available at http://www.apecsec.org.sg/member/apecmemb.html.

${ }^{6}$ Revealingly, in Bob Hawke's initial proposal the US was not included, reflecting the primacy of the East Asia region in Australian thinking. Such a grouping would have been of less use to Japan, however, as it would have been less effective in tying the US to the region strategically, nor would it have provided a vital mechanism with which to mange the problematic trade relations with the US and keep open US markets. See Higgott et al (1990).

${ }^{7}$ For brief biographies of the EPG members, see the Eminent Persons Group (1993:71-5).

${ }^{8}$ A recent survey of APEC members found that an 'extraordinary variety' of tariff and nontariff barriers remain in place, often at levels of 200 per cent or more in sensitive high valueadded industries like car production (CEDA 1995).

${ }^{9}$ For a detailed overview of APEC's proposed reform agenda, see APEC Secretariat (1995).

Some of the more salient points that might be briefly mentioned here which are likely to impact on national political-economies and existent distributional coalitions are: a desire to promote 'transparency' with regard to legal and regulatory processes; the pursuit of non-discrimination in trade and investment outcomes; the encouragement of competition policies as a central organising mechanism within APEC economies.

${ }^{10}$ For overviews of the postwar international economic system's development see Gilpin (1987) and Block (1977).

11 There are by now a number of cogent critiques of the IMF approach which centre on the inappropriateness of fiscal austerity for countries experiencing a crisis of private sector debt; the favouring of external lenders over domestic reconstruction; the IMF's own lack of transparency; the IMF's role in exacerbating the 'moral hazard' problem. See Radelet and Sachs (1998). 12 Indeed, it is instructive to compare the way the IMF has treated nuclear-armed Russia which has been able to flout IMF demands with relative impunity. (See The Economist July 11, 1998). ${ }^{13}$ Detailed statements of the proposed changes to the financial sectors of Thailand and Indonesia are available through the IMF's homepage. For a detailed critique of the IMF's approach to the crisis and its impact on the Korean-style high debt model, see Wade and Veneroso (1998).

\section{References}

APEC Secretariat (1995) Selected APEC Documents, Singapore: APEC.

Ariff, M. (1994) 'The role of APEC: An Asian perspective', Journal of Japanese Trade and Industry, 13 (1): 46-9. 
Beeson, M. (1996) 'Asia's disparate political economies and the prospects for transnational "convergence"', Asian Journal of Public Administration, 18 (2) : 141-67.

- (1998) 'Indonesia, the East Asian crisis, and the commodification of the nation-state', New Political Economy, 3 (3): 357-74.

- (forthcoming a) 'The end of the miracle? Japan and the East Asian crisis', Political Science.

- (forthcoming b) 'The political-economy of East Asia at a time of crisis', in Richard Stubbs and Geoffrey R.D. Underhill (eds.), Political Economy and the Changing Global Order, 2nd Edition, Oxford University Press.

Beeson, M. and Jayasuriya, K. (1998) 'The political rationalities of regionalism: APEC and the EU in comparative perspective', The Pacific Review, 11 (3): 311-36.

Bello, W and Rosenfeld, S (1990) Dragons in Distress: Asia's Miracle Economies in Crisis, London: Penguin Books.

Berger, M. and Beeson, M. (1998) ‘Lineages of liberalism and miracles of modernization: The World Bank, the East Asian trajectory and the international development debate', Third World Quarterly, 19 (3): 487-504.

Berger, P. L. and Luckmann, T. (1971) The Social Construction of Reality: A Treatise on the Sociology of Knowledge, London: Penguin Books.

Bergsten, C.F. (1994) 'APEC and world trade: a force for worldwide liberalisation', Foreign Affairs, 73 (3): 20-26.

Block, F.L. (1977) The Origins of International Economic Disorder, (Berkeley: University of California Press.

Bullard, N. et al (1998) 'Taming the tigers: The IMF and the Asian crisis', in Jomo, K.S. (ed.), Tigers in Trouble: Financial Governance, Liberalisation and Crises in East Asia, London: Zed Books: 85-136.

Castells, M. (1992) 'Four Asian tigers with a dragon head: a comparative analysis of the state, economy, and society in the Asian pacific Rim, in Appelbaum, R.P. \& Henderson, J. (eds) States and Development in the Asian Pacific Rim, Newbury Park: Sage, pp 33-70. 
CEDA (Committee for Economic Development of Australia, 1995) APEC and Australian Business: Evaluating the Opportunities Targeting Impediments to Trade, Sydney: CEDA.

Dibb, P. et al (1998) 'The strategic implications of Asia's economic crisis', Survival, 40 (2): 5-26.

Dirlik, A (1992) 'The Asia-Pacific idea: reality and representation in the invention of regional structure', Journal of World History, 3 (1): 55-79.

Dobson, W \& Lee Tsao Yuan (1994) 'APEC: Co-operation amidst Diversity', ASEAN Economic Bulletin, 10 (3) : 231-44.

Drysdale, P. (1988) International Economic Pluralism: Economic Policy in East Asia and the Pacific, Sydney: Allen \& Unwin.

Drysdale, P. and Garnaut, R. (1993) 'The Pacific: An application of a general theory of economic integration', in Bergsten, C.F. and Noland, M. (eds.), Pacific Dynamism and the International Economic System, Washington: Institute of International Economics: 183-223.

Eminent Persons Group (1993) A Vision for APEC: Towards and Asia Pacific Economic Community, Singapore: Asia-Pacific Economic Cooperation.

Elek, A (1995) 'APEC beyond Bogor: an open economic association in the AsianPacific region', Asian-Pacific Economic Literature, 9 (1): 1-16.

Funabashi, Y. (1995) Asia Pacific Fusion: Japan's Role in the APEC, Washington: Institute for International Economics.

Garran, R. (1995) 'Asians 'concerned' by APEC deadlines', The Weekend Australian, 25-26 February: 14.

Gerlach, M. (1992) Alliance Capitalism: The Social Organization of Japanese Business, University of California Press, Berkeley.

Gill, S. (1993) 'Neo-liberalism and the Shift Towards a US-centred Transnational Hegemony', in Henk Overbeek (ed) Restructuring Hegemony in the Global Political Economy: The Rise of Transnational Neoliberalism in the 1980s, London: Routledge: 246-82.

- (1997) 'Finance, production and panopticism: inequality, risk and resistance in an era of disciplinary neo-liberalism', in Gill, S (ed) Globalization, Democratization and Multilateralism, London: Macmillan: 51-75 
Gilpin, R. (1987) The Political Economy of International Relations, Princeton: Princeton University Press.

Goldstein, J \& Keohane, R O (1993) ‘Ideas and Foreign Policy: An Analytical Framework', in Goldstein, J \& Keohane, R O (eds) Ideas and Foreign Policy: Beliefs, Institutions and Political Change, Ithaca: Cornell University Press: 330.

Gomez, E.T. (1994) Political Business: Corporate Involvement of Malaysian Political Parties, Townsville: James Cook University.

Hall, P. (1986) Governing the Economy: The Politics of State Intervention in Britain and France, Oxford: Oxford University Press.

Hall. P. A. and Taylor, R.C.R. (1996) 'Political science and the three new institutionalisms', Political Studies, 44: 936-57.

Hatch, W. and Yamamura, K. (1996) Asia in Japan's Embrace: Building a Regional Production Alliance, Cambridge: Cambridge University Press.

Higgott, R. (1998) 'The Asian economic crisis: A study in the politics of resentment', New Political Economy, 3 (3).

Huntington, S.P. (1993) 'Why international primacy matters', International Security, 17 (4): 68-83.

- (1996) The Clash of Civilizations and the Remaking of World Order, New York: Simon \& Schuster.

Higgott, R. et al (1990) 'Asia-Pacific Economic Cooperation: An evolving casestudy in leadership and co-operation building', International Journal, 45: 823-66.

Fischer, S. (1997) 'Capital account liberalization and the role of the IMF', IMF Seminar: Asia and the IMF, September 19. http://www.imf.org/external/np/speeches/1997/0911997.htm

IMF (1998) The IMF's Response to the Asian Crisis, IMF: http://www.imf.org/External/np/exr/facts/asia.HTM

Ito, S. (1995) 'US backs APEC to mediate on trade', The Weekend Australian, 8-9 July: 17.

Jayasuriya, K. (1996) 'The rule of law and capitalism in East Asia', The Pacific Review, 9 (3):367-88. 
Johnson, C. (1982) MITI and the Japanese Miracle: The Growth of Industry Policy 1925-1975, Stanford: Stanford University Press.

Keohane, R.O. (1984) After Hegemony: Cooperation and Discord in the World Political Economy, Princeton: Princeton University Press.

- (1989) International Institutions and State Power: Essays in International Relations Theory, Boulder: Westview Press.

Kelly, P. (1997) 'US imperatives rule in maturing APEC', The Australian, November 27.

Korhonen, P. (1994) Japan and the Pacific free Trade Area, London: Routledge.

Landes, D.S. (1998) The Wealth and Poverty of Nations: Why Some Are So Rich and Some So Poor, New York: W.W. Norton.

Lane, R.E. (1991) The Market Experience, Cambridge: Cambridge University Press.

Leys, C. (1996) 'Rational choice or Hobson's choice? The "new political economy" as development theory', Studies in Political Economy, 49, Spring: 37-69.

Mayhew, A. (1987) 'Culture: core concept under attack', Journal of Economic Issues, 21 (2): 587-603.

Milner, H. (1992) 'International theories of cooperation among nations: Strengths and weaknesses', World Politics, 44, (3): 466-96.

Ministry of Fiance and the Economy (1997) 'The IMF Program: Comprehensive Implementation Action and Plans (Summary)', Seoul:

http://kiep.go.kr/IMF/hot-2.html

North, D.C. (1990a) Institutions, Institutional Change and Economic Performance, Cambridge: Cambridge University Press.

- (1990b) 'Institutions and their consequences for economic performance', in K. S. Cook \& M. Levi (eds) The Limits of Rationality, Chicago: The University of Chicago Press.

- (1994) 'Economic performance through time', The American Economic Review, 84 (3): 359-68. 
- (1995) 'The new institutional economics and Third World development', in John Harriss et al, (eds) The New Institutional Economic and Third World Development, London: Routledge: 17-26.

Pauly, L.P. (1997) Who Elected the Bankers? Surveillance and Control in the World Economy, Ithaca: Cornell University Press.

Radelet, S. and Sachs, J. (1998) The Onset of the Asian Financial Crisis, World Wide Web document, URL:

$<$ http://www.stern.nyu.edu/ nroubini/asia/AsiaHomepage.html >

Rapkin, D et al (1997) 'Institutional adjustment to changed power distributions: Japan and the United States in the IMF', Global Governance, 3 : 171-95.

Ravenhill, J (1995) 'Competing logics of regionalism in the Asia-Pacific', Journal of European Integration, 18 (2-3): 179-99.

Robison, R. and Rosser, A. (forthcoming) 'Contesting reform: Indonesia's New Order and the IMF', World Development.

Ruggie, J. G. (1982) 'International regimes, transactions, and change: embedded liberalism in the postwar economic order', International Organization, 36 (2): 379-415.

- (1996) Winning the Peace: America and World Order in the New Era, New York: Columbia University Press.

Ruigrok, W. and van Tulder, R. (1995) The Logic of International Restructuring, London, Routledge.

Rutherford, M. (1994) Institutions in Economics: The Old and New Institutionalism, Cambridge: Cambridge University Press.

Soesastro, H. (1994) 'Pacific economic cooperation: A historical exploration', in Soesastro, $\mathrm{H}$ (ed) Indonesian Perspectives on APEC and Regional Cooperation in Asia Pacific, Jakarta: Centre for Strategic and International Studies.

Stewart, I. (1996) 'Mahathir uses UN speech to attack the West', The Australian, 30 September: 14.

Stubbs, R. (1994) 'The political economy of the Asia-pacific region', in Stubbs, R. \& Underhill, G. (eds) Political Economy and the Changing Global Order, London: Macmillan: 366-77. 
Wade, R. (1990) Governing the Market: Economic Theory and the Role of Government in East Asian Industrialization, Princeton: Princeton University Press.

Wade, R. and Veneroso, F. (1998) 'The Asian crisis: The high debt model versus the Wall Street-Treasury-IMF complex', New Left Review, 228: 3-23.

Wendt, A. (1992) 'Anarchy is what states make of it: the social construction of power politics', International Organisation, 46 (2): 391-425.

Williams, D. and Young, T. (1994) 'Governance, the World bank and Liberal Theory', Political Studies, 42: 84-100.

Williamson, John (1994) 'In Search of a Manual for Technopols'. In J. Williamson (ed.), The Political Economy of Policy Reform. Washington: Institute for International Economics, pp 11-28.

Williamson, O.E. (1985) The Economic Institutions of Capitalism: Firms, Markets Relational Contracting, New York: The Free Press.

- (1993) 'Transaction cost economics and organisation theory', Industrial and Corporate Change, 2 (2): 107-56.

Woods, L (1993) Asia-Pacific Diplomacy: Nongovernmental Organisations and International Relations, Vancouver: UBC Press.

Zysman, J. (1994) 'How institutions create historically rooted trajectories of growth', Industrial and Corporate Change, 3 (1): 243-83. 